\title{
Characterization of TB/HIV Co-Infected Patients Receiving TB Treatment at a DOTS Clinic, in a Tertiary Hospital in South-Eastern Nigeria
}

\author{
Echendu D. Adinma, Darlington C. Obi* Emmanuel C. Azuike, Victor A. Mbanuzuru, \\ Ifeoma C. Iloghalu \\ Department of Community Medicine, Nnamdi Azikiwe University Teaching Hospital, Nnewi, Nigeria \\ Email: *dclondon4u@yahoo.com
}

Received 10 September 2015; accepted 27 October 2015; published 30 October 2015

Copyright (C) 2015 by authors and Scientific Research Publishing Inc.

This work is licensed under the Creative Commons Attribution International License (CC BY).

http://creativecommons.org/licenses/by/4.0/

(c) (i) Open Access

\begin{abstract}
Background: Tuberculosis (TB) is a specific infectious disease caused by mycobacterium tuberculosis while acquired immune deficiency syndrome (AIDS) is a fatal illness caused by human immunodeficiency virus (HIV). Both of them constitute the main burden of infectious public health disease in many parts of the world, particularly in resource limited countries like Nigeria. This study sets out to describe TB/HIV co-infected patients accessing care at the DOTS clinic in a tertiary hospital in South-Eastern Nigeria. Methods: This study was conducted retrospectively at the DOTS clinic of NAUTH Nnewi. A structured proforma was used to extract specific characteristics of TB/HIV co-infected patients who received TB treatment for the period of $1^{\text {st }}$ January 2013 to $31^{\text {st }}$ December 2013. The collected data were analyzed with SPSS version 20 . Results: Ninety eight patients $(40.6 \%)$ were TB/HIV co-infected, out of the two hundred and forty one patients treated for tuberculosis in the DOTS clinic during the period under review. These were the findings among the TB/HIV co-infected patients: there were more females (51\%) than males (49\%); the commonest age group affected was the group 30 - 39 years $(34.7 \%)$; majority of the patients $(91.8 \%)$ had pulmonary TB as against extrapulmonary TB (8.2\%) and most of the patients had negative sputum AFB result (43.9\%) as against those with positive result $(36.7 \%)$. Conclusion: This study demonstrated some important characteristics of TB/HIV co-infected patients. Such knowledge if taken into consideration in both the tuberculosis control and HIV control programs will improve the outcomes of the programs.
\end{abstract}

\section{Keywords}

Characterization, TB/HIV, Co-Infected Patients

\footnotetext{
"Corresponding author.
}

How to cite this paper: Adinma, E.D., Obi, D.C., Azuike, E.C., Mbanuzuru, V.A. and Iloghalu, I.C. (2015) Characterization of TB/HIV Co-Infected Patients Receiving TB Treatment at a DOTS Clinic, in a Tertiary Hospital in South-Eastern Nigeria. Journal of Tuberculosis Research, 3, 113-121. http://dx.doi.org/10.4236/itr.2015.34017 


\section{Introduction}

Tuberculosis (TB) is a specific infectious disease caused by mycobacterium tuberculosis while acquired immune deficiency syndrome (AIDS) is a fatal illness caused by human immunodeficiency virus (HIV). Both of them constitute the main burden of infectious public health disease in many parts of the world, particularly in resource limited countries like Nigeria. Worldwide, the number of people infected with both HIV and TB is rising and to make the global situation worse, TB has formed a lethal partnership with HIV. The HIV virus damages the body's natural defenses and the immune system and accelerates the speed at which tuberculosis progresses from a harmless infection to a life-threatening condition. People with HIV are at risk of being newly infected, if they are exposed to TB because their weakened immune system makes them more vulnerable. This results to premature death if left untreated. This unholy association between TB and HIV means that people suffer additional discrimination.

The estimated 10 percent activation of dormant TB infection over the life span of an infected person is increased to 10 percent activation in one year, if HIV infection is superimposed [1]. Also, people who are infected with both TB and HIV are 25 - 30 times more likely to develop active TB disease than people infected only with TB [1]. Sentinel surveillance in Nigeria in 2001 showed the prevalence of HIV among TB patients to be 19.1\% [2]. The HIV sero-prevalence in TB patients worldwide has underscored the urgent need to screen all suspected TB patients for HIV infection. According to surveillance and survey data, estimates by the World Health Organization (WHO) show that there are more than 9 million new active cases of $\mathrm{Tb}$ and close to 2 million deaths per year [3] and that 2.6 million new cases of HIV infection and 1.8 million AIDS-related deaths occur per year [4].

It is estimated that about 14 million individuals worldwide are TB/HIV co-infected [5]. TB is known to be the most common opportunistic disease and the single largest cause of death in the setting of HIV/AIDS [6], accounting for about $26 \%$ of AIDS related deaths [5], 99\% of which occur in resource limited countries [7]. In 2011, 1.1 million (13\%) of the 8.7 million people who developed TB worldwide were HIV positive [8]. TB/HIV co-infection poses serious diagnostic and therapeutic challenges and exerts great pressure on health care delivery systems in Africa and Asian countries with large populations of co-infected persons. This study sets out to describe TB/HIV co-infected patients accessing care at the DOTS clinic in a tertiary hospital in South-eastern Nigeria.

\section{Methodology}

This study was conducted retrospectively at the DOTS clinic of Nnamdi Azikiwe University Teaching Hospital (NAUTH) Nnewi. The hospital is a tertiary hospital. The source of data was the clinic register. A structured proforma was used to extract specific characteristics of TB/HIV co-infected patients who received TB treatment for the period of $1^{\text {st }}$ January 2013 to $31^{\text {st }}$ December 2013. Characteristics sought included age, sex, weight, place of residence, sputum AFB status, site of TB infection, treatment regimen, and category of patients.

The collected data were entered into international business machines-statistical package for social sciences (IBM-SPSS) version 20, and analysed. Results were presented in tables showing frequencies and percentages for easy appreciation. Chi square test was used to determine association between socio-demographic characteristics and some categorical variables including site of disease, sputum AFB status, antiretroviral status, treatment regimen etc. Ethical approval was sought for and obtained by the Nnamdi Azikiwe University Teaching Hospital Ethical Committee (NAUTHEC).

\section{Results}

Ninety eight patients (40.6\%) were TB/HIV co-infected, out of the two hundred and forty one patients treated for tuberculosis in the DOTS clinic during the period under review.

Table 1 showed the demographic characteristics of the patients. There were more females (51\%) than males (49\%). The commonest age group affected was the group 30 - 39 years (34.7\%). The commonest weight of the patients was the range of $50-59.9 \mathrm{~kg}(29.6 \%)$. Majority of the patients (62.2\%) were urban dwellers while (37.8\%) were rural dwellers.

Table 2 showed that majority of the patients (91.8\%) had pulmonary TB as against extrapulmonary TB (8.2\%). Most of the patients had negative sputum AFB result (43.9\%) as against those with positive result 
Table 1. Socio-demographic characteristics of the patients.

\begin{tabular}{ll}
\hline Variable & Frequency (\%) $\mathbf{N}=\mathbf{9 8}$ \\
\hline Sex & \\
Male & $48(49.0)$ \\
Female & $50(51.0)$ \\
Total & $\mathbf{9 8}(\mathbf{1 0 0 . 0 )}$ \\
Age (in years) & \\
$<20$ & $24(24.5)$ \\
$20-29$ & $10(10.2)$ \\
$30-39$ & $34(34.7)$ \\
$40-49$ & $22(22.4)$ \\
$50-59$ & $7(7.1)$ \\
$60-69$ & $1(1.0)$ \\
Total & $\mathbf{9 8}(\mathbf{1 0 0 . 0})$ \\
Weight (kg) & \\
$<20$ & $12(12.2)$ \\
$20-29.99$ & $7(7.1)$ \\
$30-39.99$ & $4(4.1)$ \\
$40-49.99$ & $22(22.4)$ \\
$50-59.99$ & $29(29.6)$ \\
$60-69.99$ & $16(16.3)$ \\
$70-79.99$ & $7(7.1)$ \\
Missing & $1(1.0)$ \\
Residence & \\
Urban & $61(62.2)$ \\
Rural & $37(37.8)$ \\
Total & $\mathbf{9 8}(\mathbf{1 0 0 . 0})$ \\
&
\end{tabular}

Table 2. Distribution of patients by disease site, AFB status, treatment regimen and antiretroviral treatment status.

\begin{tabular}{ll}
\hline Variable & Frequency (\%) $\mathbf{N}=\mathbf{9 8}$ \\
\hline Disease site & $90(91.8)$ \\
Pulmonary & $8(8.2)$ \\
Extrapulmonary & $\mathbf{9 8}(\mathbf{1 0 0 . 0})$ \\
Total & \\
AFB status & $36(36.7)$ \\
Positive & $43(43.9)$ \\
Negative & $15(15.3)$ \\
Unable to produce sputum & $3(3.1)$ \\
Others & $1(1.0)$ \\
Missing & $\mathbf{9 8}(\mathbf{1 0 0 . 0})$ \\
Total & \\
Treatment regimen: & $94(95.9)$ \\
Category 1 & $4(4.1)$ \\
Category 2 & $\mathbf{9 8}(\mathbf{1 0 0 . 0 )}$ \\
Total & \\
Antiretroviral treatment status & $46(46.9)$ \\
On treatment & $52(53.1)$ \\
Not on treatment & \\
\hline
\end{tabular}


(36.7\%) while $15 \%$ of them (mainly children) were unable to produce sputum. Majority of the patients (95.9\%) received category 1 anti-Kochi's regimen as against category 2 regimen (4.1\%). Most of them (53.1\%) were not on treatment for HIV infection as against those on treatment (46.9\%).

Table 3 showed that a greater proportion of the co-infected patients were in the age range 30 - 39 (34.7\%) while the least was the age range of $60-69(2.0 \%)$ and this was statisticlaly significant $\left(X^{2}=12.869, p=0.025\right)$. There was also a statistically significant association between sex and weight of the patients $\left(X^{2}=14.986, p=0.036\right)$.

Table 4 showed that there was no association between the place of residence of the patients (urban/rural) and the following variables: gender, age, weight, site of disease, sputum AFB status, antiretroviral treatment status and tuberculosis treatment regimen.

Table 3. Association between sex of patients and other variables.

\begin{tabular}{|c|c|c|c|c|c|}
\hline Variables & $\begin{array}{l}\text { Male }(\mathrm{N}=48) \\
\mathrm{n}(\%)\end{array}$ & $\begin{array}{l}\text { Female }(\mathrm{N}=50) \\
\mathrm{N}(\%)\end{array}$ & Total & $\mathrm{X}^{2}$ & p Value \\
\hline \multicolumn{6}{|l|}{ Age groups (years) } \\
\hline$<20$ & $16(33.3)$ & $8(16.0)$ & $24(24.5)$ & 12.869 & $0.025^{*}$ \\
\hline $20-29$ & $1(2.1)$ & $9(18.0)$ & $10(10.2)$ & & \\
\hline $30-39$ & $14(29.2)$ & $20(40.0)$ & $34(34.7)$ & & \\
\hline $40-49$ & $14(29.2)$ & $8(16.0)$ & $22(22.4)$ & & \\
\hline $50-59$ & $3(6.2)$ & $4(8.0)$ & $7(7.1)$ & & \\
\hline $60-69$ & $0(0.0)$ & $1(2.0)$ & $1(2.0)$ & & \\
\hline \multicolumn{6}{|l|}{ Weight (kg) } \\
\hline$<20$ & $8(16.7)$ & $4(8.0)$ & $12(12.2)$ & 14.986 & $0.036 *$ \\
\hline $20-29.9$ & $5(10.4)$ & $2(4.0)$ & $7(7.1)$ & & \\
\hline $30-39.9$ & $1(2.1)$ & $3(6.0)$ & $4(4.1)$ & & \\
\hline $40-49.9$ & $5(10.4)$ & $17(34.0)$ & $22(22.4)$ & & \\
\hline $50-59.9$ & 15 (31.2) & $14(28.0)$ & 29 (29.6) & & \\
\hline $60-69.9$ & $7(14.6)$ & $9(18.0)$ & $16(16.3)$ & & \\
\hline $70-79.9$ & $6(12.5)$ & $1(2.0)$ & $7(7.1)$ & & \\
\hline 999 & $1(2.1)$ & $0(0.0)$ & $1(1.0)$ & & \\
\hline \multicolumn{6}{|l|}{ Residence } \\
\hline Urban & $33(68.8)$ & $28(56.0)$ & $61(62.2)$ & 1.694 & 0.193 \\
\hline Rural & 15 (31.2) & $22(44.0)$ & $37(37.8)$ & & \\
\hline \multicolumn{6}{|l|}{ Site of disease } \\
\hline Pulmonary & 43 (89.6) & 47 (94.0) & 90 (91.8) & 0.637 & 0.425 \\
\hline Extrapulmonary & $5(10.4)$ & $3(6.0)$ & $8(8.2)$ & & \\
\hline \multicolumn{6}{|l|}{ Sputum AFB status } \\
\hline Positive & 17 (36.2) & 19 (38.0) & $36(37.1)$ & 3.161 & 0.367 \\
\hline Negative & 18 (38.3) & $25(50.0)$ & $43(44.3)$ & & \\
\hline Unable to produce sputum & $10(21.3)$ & $5(10.0)$ & $15(15.5)$ & & \\
\hline Others & $2(4.3)$ & $1(2.0)$ & $3(3.1)$ & & \\
\hline \multicolumn{6}{|c|}{ Antiretroviral treatment status } \\
\hline On treatment & $21(43.8)$ & $25(50.0)$ & 46 (46.9) & 0.384 & 0.535 \\
\hline Not on treatment & $27(56.2)$ & $25(50.0)$ & $52(53.1)$ & & \\
\hline \multicolumn{6}{|l|}{ Treatment Regimen } \\
\hline Category 1 & 46 (95.8) & $48(96.0)$ & 94 (95.9) & 0.002 & 0.967 \\
\hline Category 2 & $2(4.2)$ & $2(4.0)$ & $4(4.1)$ & & \\
\hline
\end{tabular}

*Statistically significant. 
Table 4. Association between residence of patients and other variables.

\begin{tabular}{|c|c|c|c|c|c|}
\hline Variables & Urban (N = 61) n (\%) & Rural (N = 37) n (\%) & Total & $\mathrm{X}^{2}$ & p Value \\
\hline \multicolumn{6}{|l|}{ Sex } \\
\hline Male & $33(54.1)$ & 15 (40.5) & $48(49.0)$ & 1.694 & 0.193 \\
\hline Female & $28(45.9)$ & $22(59.5)$ & $50(51.0)$ & & \\
\hline \multicolumn{6}{|l|}{ Age } \\
\hline$<20$ & $13(21.3)$ & $11(29.7)$ & $24(24.5)$ & 3.439 & 0.633 \\
\hline $20-29$ & $6(9.8)$ & $4(10.8)$ & $10(10.2)$ & & \\
\hline $30-39$ & 24 (39.3) & $10(27.0)$ & $34(34.7)$ & & \\
\hline $40-49$ & $14(23.0)$ & $8(21.6)$ & $22(22.4)$ & & \\
\hline $50-59$ & $4(6.6)$ & $3(8.1)$ & $7(7.1)$ & & \\
\hline $60-69$ & $0(0.0)$ & $1(2.7)$ & $1(1.0)$ & & \\
\hline \multicolumn{6}{|l|}{ Weight (kg) } \\
\hline$<20$ & $5(8.2)$ & 7 (18.9) & $12(12.2)$ & 6.507 & 0.482 \\
\hline $20-29.9$ & $4(6.6)$ & $3(8.1)$ & $7(7.1)$ & & \\
\hline $30-39.9$ & $3(4.9)$ & $1(2.7)$ & $4(4.1)$ & & \\
\hline $40-49.9$ & $14(23.0)$ & $8(21.6)$ & $22(22.4)$ & & \\
\hline $50-59.9$ & $16(26.2)$ & $13(35.1)$ & 29 (29.6) & & \\
\hline $60-69.9$ & $12(19.7)$ & $4(10.8)$ & $16(16.3)$ & & \\
\hline $70-79.9$ & $6(9.8)$ & $1(2.7)$ & $7(7.1)$ & & \\
\hline Missing & $1(1.6)$ & $0(0.0)$ & $1(1.0)$ & & \\
\hline \multicolumn{6}{|l|}{ Site of disease } \\
\hline Pulmonary & $55(90.2)$ & 35 (94.6) & $90(91.8)$ & 0.603 & 0.437 \\
\hline Extrapulmonary & $6(9.8)$ & $2(5.4)$ & $8(8.2)$ & & \\
\hline \multicolumn{6}{|l|}{ Sputum AFB Status } \\
\hline Positive & $21(35.0)$ & $15(40.5)$ & $36(37.1)$ & 2.077 & 0.557 \\
\hline Negative & $27(45.0)$ & $16(43.2)$ & $43(44.3)$ & & \\
\hline Unable to produce sputum & $9(15.0)$ & $6(16.2)$ & $15(15.5)$ & & \\
\hline Others & $3(5.0)$ & $0(0.0)$ & $3(3.1)$ & & \\
\hline \multicolumn{6}{|c|}{ Antiretroviral treatment status } \\
\hline On treatment: & $30(49.2)$ & $16(43.2)$ & $46(46.9)$ & 0.326 & 0.568 \\
\hline Not on treatment & $31(50.8)$ & $21(56.6)$ & $52(53.1)$ & & \\
\hline \multicolumn{6}{|l|}{ Treatment regimen } \\
\hline Category 1 & 59 (96.7) & 35 (94.6) & $94(95.9)$ & 0.266 & 0.606 \\
\hline Category 2 & $2(3.3)$ & $2(5.4)$ & $4(4.1)$ & & \\
\hline
\end{tabular}

*Statistically significant.

Table 5 showed that there was a statistically significant association between weight of patients and site of disease $\left(X^{2}=15.611, p=0.029\right)$. However, there was no association between the site of the disease (pulmonary/extrapulmonary) and the following variables: gender, age, sputum AFB status, antiretroviral treatment status, tuberculosis treatment regimen, place of residence.

Table 6 showed that there was a statistically significant association between the age of the patients and their AFB status $\left(X^{2}=48.156, p=0.000\right)$. Also there was a statistically significant association between the weight of the patients and their sputum AFB status $\left(X^{2}=77.767, p=0.000\right)$. However, there was no association between their AFB status and the following characteristics: place of residence, site of disease, antiretroviral treatment status and tuberculosis treatment regimen. 
Table 5. Association between site of disease and other characteristics.

\begin{tabular}{|c|c|c|c|c|c|}
\hline Variables & Pulmonary N = 90 n \% & Extrapulmonary $\mathrm{N}=8 \mathrm{n} \%$ & Total & $\mathrm{X}^{2}$ & p Value \\
\hline \multicolumn{6}{|l|}{ Sex } \\
\hline Male & $43(47.8)$ & $5(62.5)$ & $48(49.0)$ & 0.637 & 0.425 \\
\hline Female & $47(52.2)$ & $3(37.5)$ & $50(51.0)$ & & \\
\hline \multicolumn{6}{|l|}{ Age: } \\
\hline$<20$ & $21(23.3)$ & $3(37.5)$ & $24(24.5)$ & 3.174 & 0.673 \\
\hline $20-29$ & $10(11.1)$ & $0(0.0)$ & $10(10.2)$ & & \\
\hline $30-39$ & 30 (33.3) & $4(50.0)$ & $34(34.7)$ & & \\
\hline $40-49$ & $21(23.3)$ & $1(12.5)$ & $22(22.4)$ & & \\
\hline $50-59$ & $7(7.8)$ & $0(0.0)$ & $7(7.1)$ & & \\
\hline $60-69$ & $1(1.1)$ & $0(0.0)$ & $1(1.0)$ & & \\
\hline \multicolumn{6}{|l|}{ Weight category } \\
\hline$<20$ & $11(12.2)$ & $1(12.5)$ & $12(12.2)$ & 15.611 & $0.029 *$ \\
\hline $20-29.9$ & $6(6.7)$ & $1(12.5)$ & $7(7.1)$ & & \\
\hline $30-39.9$ & $4(4.4)$ & $0(0.0)$ & $4(4.1)$ & & \\
\hline $40-49.9$ & $21(23.3)$ & $1(12.5)$ & $22(22.4)$ & & \\
\hline $50-59.9$ & $25(27.8)$ & $4(50.0)$ & 29 (29.6) & & \\
\hline $60-69.9$ & $16(17.8)$ & $0(0.0)$ & $7(7.1)$ & & \\
\hline $70-79.9$ & $7(7.8)$ & $0(0.0)$ & $7(7.1)$ & & \\
\hline \multicolumn{6}{|l|}{ Sputum AFB Status } \\
\hline Positive & $36(40.0)$ & $0(0.0)$ & $36(37.1)$ & 5.121 & 0.163 \\
\hline Negative & $38(42.2)$ & $5(71.4)$ & $43(44.3)$ & & \\
\hline Unable to produce sputum & $13(14.4)$ & $2(28.6)$ & $15(15.5)$ & & \\
\hline Others & $3(3.3)$ & $0(0.0)$ & $3(3.1)$ & & \\
\hline \multicolumn{6}{|c|}{ Antiretroviral treatment status } \\
\hline On treatment: & $42(46.7)$ & $4(50.0)$ & 46 (46.9) & 0.033 & 0.856 \\
\hline Not on treatment & $48(53.3)$ & $4(50.0)$ & $52(53.1)$ & & \\
\hline \multicolumn{6}{|l|}{ Treatment Regimen } \\
\hline Category 1 & $86(95.6)$ & $8(10.0)$ & $94(95.9)$ & 0.371 & 0.543 \\
\hline Category 2 & $4(4.4)$ & $0(0.0)$ & $4(4.1)$ & & \\
\hline \multicolumn{6}{|l|}{ Residence } \\
\hline Urban & $55(61.1)$ & $6(75.0)$ & $61(62.2)$ & 0.603 & 0.437 \\
\hline Rural & 35 (38.9) & $2(25.0)$ & $37(37.8)$ & & \\
\hline
\end{tabular}

*Statistically significant.

\section{Discussion}

In this study there were more female than male TB/HIV co-infected patients. This is similar to the finding of a study done at Enugu, Nigeria where there were more female TB/HIV co-infected patients [9]. The commonest age group was the group 30 - 39 years. This is similar to the findings of other studies [10] [11] and agrees with the generally accepted knowledge that TB affects the reproductive age groups [12].

In this study there were more urban patients than rural patients. This contrasts with the findings of a study 
Table 6. Association between sputum AFB status and other characteristics.

\begin{tabular}{|c|c|c|c|c|c|c|c|}
\hline Variable & $\begin{array}{l}\text { Positive N = } 35 \\
\text { n (\%) }\end{array}$ & $\begin{array}{l}\text { Negative } N=43 \\
\text { n (\%) }\end{array}$ & $\begin{array}{l}\text { Unable to produce } \\
\mathrm{N}=15 \mathrm{n}(\%)\end{array}$ & $\begin{array}{l}\text { Others } N=3 \\
\text { n (\%) }\end{array}$ & Total & $\mathrm{X}^{2}$ & p Value \\
\hline \multicolumn{8}{|l|}{ Age } \\
\hline$<20$ & $1(2.8)$ & 9 (20.9) & 13 (86.7) & 1 (33.1) & $24(24.7)$ & 48.156 & $0.000 *$ \\
\hline $20-29$ & $5(13.9)$ & $5(11.6)$ & $0(0.0)$ & $0(0.0)$ & $10(10.3)$ & & \\
\hline $30-39$ & 15 (41.7) & $16(37.2)$ & $1(6.7)$ & 1 (33.3) & $33(34.0)$ & & \\
\hline $40-49$ & $13(5.6)$ & $8(18.6)$ & $1(6.7)$ & $0(0.0)$ & $22(227)$ & & \\
\hline$-50-59$ & $2(5.6)$ & $4(9.3)$ & $0(0.0)$ & 1 (33.3) & $7(7.2)$ & & \\
\hline $60-69$ & $0(0.0)$ & $1(2.3)$ & $0(0.0)$ & $0(0.0)$ & $1(1.0)$ & & \\
\hline \multicolumn{8}{|l|}{ Weight } \\
\hline$<20$ & $0(0.0)$ & $1(2.3)$ & $11(73.3)$ & $0(0.0)$ & $12(12.4)$ & 77.767 & $0.000 *$ \\
\hline $20-29.9$ & $0(0.0)$ & 5 (11.6) & $1(6.7)$ & 1 (33.3) & $7(7.2)$ & & \\
\hline $30-39.9$ & $1(2.8)$ & $3(7.0)$ & $0(0.0)$ & $0(0.0)$ & $4(4.1)$ & & \\
\hline $40-49.9$ & $7(2.8)$ & 12 (27.9) & $2(13.3)$ & 1 (33.3) & $22(22.7)$ & & \\
\hline $50-59.9$ & 14 (38.9) & $13(30.2)$ & $1(6.7)$ & $0(0.0)$ & 28 (28.9) & & \\
\hline $60-69.9$ & $9(25.0)$ & $6(14.0)$ & $0(0.0)$ & $1(33.3)$ & 16 (16.5) & & \\
\hline $70-79.9$ & 5 (13.9) & $2(4.7)$ & $0(0.0)$ & $0(0.0)$ & $7(7.2)$ & & \\
\hline \multicolumn{8}{|l|}{ Residence } \\
\hline Urban & $21(58.3)$ & 27 (62.6) & $9(60.0)$ & $3(100.0)$ & $60(61.9)$ & 2.077 & 0.557 \\
\hline Rural & 15 (51.7) & $16(37.2)$ & $6(40.0)$ & $0(0.0)$ & 37 (38.1) & & \\
\hline \multicolumn{8}{|l|}{ Site of disease } \\
\hline Pulmonary & $36(100.0)$ & 38 (88.4) & $13(86.7)$ & $3(100.0)$ & $90(92.8)$ & 5.121 & 0.163 \\
\hline Extrapulmonary & $0(0.0)$ & 5 (11.6) & $2(13.3)$ & $0(0.0)$ & $7(7.2)$ & & \\
\hline \multicolumn{8}{|c|}{ Antiretroviral treatment status } \\
\hline On treatment: & $20(55.6)$ & $21(48.8)$ & $3(20.0)$ & $1(33.3)$ & $45(46.4)$ & 5.726 & 0.126 \\
\hline Not on treatment & $16(44.4)$ & $22(51.2)$ & $12(80.0)$ & $2(66.7)$ & $52(53.6)$ & & \\
\hline \multicolumn{8}{|c|}{ Treatment Regimen } \\
\hline Category 1: & $34(94.4)$ & $41(95.3)$ & $15(100.0)$ & $3(100.0)$ & $93(95.9)$ & 0.991 & 0.803 \\
\hline Category 2: & $2(5.6)$ & $2(4.7)$ & $0(0.0)$ & $0(0.0)$ & $4(4.1)$ & & \\
\hline
\end{tabular}

*Statistically significant.

done in Pakistan [13] but agrees with the finding of another study done in India where the urban patients were more [14]. More patients had pulmonary TB (91.8\%) than extrapulmonary TB (8.2\%). Similar findings were reported in other studies [15]-[17] and agreed with generally accepted prevalence of extrapulmonary TB among all cases of TB [18]. More clients in this study had sputum AFB negative results than sputum positive results. Several studies have reported such findings [19] [20]. HIV is generally known to be more in the reproductive age [21] [22]. This was corroborated in this study as the commonest age group (30 - 39 years) is among the reproductive age group. This is understandable because the commonest mode of transmission of HIV remains the sexual route [22] [23], and these age groups are the most sexually active age groups. Among the TB/HIV co-infected patients, more reside in the urban area than the rural area. This is not surprising because the prevalence of HIV in Nigeria is higher in the urban areas than in the rural areas [24] [25].

\section{Conclusions and Recommendations}

In this study, there were more female TB/HIV patients. The reproductive age group was more affected. There 
were more pulmonary TB patients than extra-pulmonary TB patients. There were more sputum AFB negative patients.

We therefore recommend as follows: there should be more rigorous case finding of TB/HIV co-infection among females. More efforts to combat TB/HIV co-infection should be channelled towards the reproductive age group. Health workers should not be in a hurry to conclude that sputum smear negative HIV patients did not have TB. Clinical diagnosis of tuberculosis in a background of tuberculosis should be intensified. Health workers should be wary of the presence of TB in HIV positive individuals. Efforts should be made to prevent HIV among youths. Adolescent friendly clinics should be established. Efforts to combat TB/HIV co-infection should be intensified in the urban areas, in as much as the rural areas should not be neglected.

\section{References}

[1] Park, K. (2009) Preventive and Social Medicine. 20th Edition, M/S Banarsidas Bhanot, Jabalpur, 175.

[2] Obionu, C.N. (2007) Primary Health Care for Developing Countries. 2nd Edition, Evans Publishers, 149.

[3] World Health Organization (2010) Global Tuberculosis Control 2010. http://www.who.int/tb/publications/global_report/2010/en/index.html

[4] UNAIDS (2010) UNAIDS Report on the Global AIDS Epidemic 2010. http://www.UNAIDS.org/documents/20101123 GlobalReport chap2 em pdf

[5] Getahun, H., Gunneberg, C., Granich, R. and Nunn, P. (2010) HIV Infection-Associated Tuberculosis: The Epidemiology and the Response. Clinical Infectious Diseases, 50, 35201-5207. http://dx.doi.org/10.1086/651492

[6] Corbett, E.L., Watt, C.J., Walker, N., Maher, D., Williams, B.G., et al. (2003) The Growing Burden of Tuberculosis: Global Trends and Interactions with the HIV Epidemic. Archives of Internal Medicine, 163, 1009-1021. http://dx.doi.org/10.1001/archinte.163.9.1009

[7] Collins, K.R., Quinones-Mateu, M.E., Toossi, Z. and Arts, E.J. (2002) Impact of Tuberculosis on HIV-1 Replication, Diversity and Disease Progression. AIDS Reviews, 4, 165-176.

[8] World Health Organization (WHO) (2012) Global Tuberculosis Report 2012. WHO Press, Geneva.

[9] Ekwueme, O.C., Ezeoke, U.E. and Mgbeokwere, U. (2009) The Prevalence and Socio-Demographic Characteristics of Persons with TB and TB/HIV Co-Infection at the Chest Clinic of the University of Nigeria Teaching Hospital, Enugu, Nigeria. Journal of College of Medicine, 14, 6-17.

[10] Donald, C., Uday, S.S., Sidhyartha, M. and Deepak, S. (2010) Socio-Demographic Profiles of the Delayed Diagnosed Patients in RNTCP. Anand District. Healthline, 1, 45-48.

[11] Lawn, S.D., Bekker, L., Middelkoop, K., Myer, L. and Wood, R. (2006) Impact of HIVI Infection on the Epidemiologyof Tuberculosis in a Peri-Urban Community in South Africa: The Need for Age-Specific Interventions. Clinical Infectious Diseases, 42, 1040-1047. http://dx.doi.org/10.1086/501018

[12] World Health Organisation (2014) Tuberculosis Fact Sheet. www.who.int/mediacentre/factsheets/fs104/en/

[13] Muhammad, U.M., Ubeera, S., Hussain, M.A., Anum, S., Fatima, O., et al. (2011) Urban-Rural Inequities in Knowledge, Attitudes and Practices Regarding Tuberculosis in Two Districts of Pakistan's Punjab Province. International Journal for Equity in Health, 10, 8. http://dx.doi.org/10.1186/1475-9276-10-8

[14] Rajewswani, R., Balasubramanian, R., Muniyadi, M., Geetharamani, S., Theresa, X. and Venkatessa, P. (1999) SocioEconomic Impact of Tuberculosis on Patients and Family in India. The International Journal of Tuberculosis and Lung Disease, 3, 869-877.

[15] Sreeramareddy, C.T., Panduru, K.V., Verma, S.C., Joshi, H.S. and Bates, M.N. (2008) Comparison of Pulmonary and Extrapulmonary Tuberculosis in Nepal—A Hospital-Based Retrospective Study. BMC Infectious Diseases, 8, 8. http://dx.doi.org/10.1186/1471-2334-8-8

[16] Noertjojo, K., Tam, C.M., Chan, S.L. and Chan-Yeung, M.M. (2002) Extra-Pulmonary and Pulmonary Tuberculosis in Hong Kong. The International Journal of Tuberculosis and Lung Disease, 6, 879-886.

[17] Musellin, B., Erturan, S., Sonmez, D.E. and Ongen, G. (2005) Comparison of Extrapulmonary and Pulmonary Tuberculosis Cases: Factors Influencing the Site of Reactivation. International Journal of Tuberculosis and Lung Disease, 9, 1220-1223.

[18] Sharma, S.K. and Mohan, A. (2012) Extrapulmonary Tuberculosis. Indian Journal of Medical Research, 136, 11291166.

[19] Ogboi, S.J., Idris, S.H., Olayinka, A.T. and Ilyas, J. (2010) Socio-Demographic Characteristics of Patients Presenting with Pulmonary Tuberculosis in a Primary Health Centre, Zaria, Nigeria. Journal of Medical Laboratory and Diagnosis, 1, 11-14. 
[20] Hamid, S., Syed, A.H. and Ali, I. (2012) Sociodemographic Factors Associated with Sputum Positivity Rates for Tuberculosis in Patients with Cough in Srinagar Hospital, India. Pacific Journal of Medical Sciences, 9, 47-52.

[21] Centres for Disease Control and Prevention (2014) HIV/AIDS Statistics. www.cdc.gov/hiv/statistics/basics/

[22] World Health Organisation (WHO) HIV/AIDS Fact Sheet. www.who.int/mediacentre/factsheets/F360/en/

[23] Marlink, R.G. and Kotin, A.G. (2004) Global AIDS Crisis: A Reference Handbook. ABC-CLIO Inc., Santa Barbara, 54.

[24] Federal Ministry of Health of Nigeria (2012) 2010 National HIV Sero-Prevalence Sentinel Survey. Federal Ministry of Health, Abuja.

[25] Obidoa, C.A. and Cromley, R.G. (2012) A Geographical Analysis of HIV/AIDS Infection in Nigeria, 1991-2001. Journal of Social, Behavioural and Health Sciences, 6, 13-29. 